\section{Did Smoke from the Kuwait Oil Well Fires Affect Iranian Archaeological Heritage?}

ALESSANDRA B ONAZZA, $*,+$

CRISTINA SABBIONI, ${ }^{\dagger}$ NADIA GHEDINI,

B ERNARDO HERMOSIN, $\$$

VALME JURADO, $§$

JUAN MIGUEL GONZALEZ, § AND

C E S A R E O S A I Z - J I M E N E Z ${ }^{\S}$

Institute of Atmospheric Sciences and Climate, National

Research Council (CNR), Via Gobetti, 101, 40129 Bologna, Italy, Department of Pharmaceutical Sciences, Via Belmeloro 6, 40126 Bologna, Italy, and Instituto de Recursos Naturales y Agrobiologia, CSIC, Apartado 1052, 41080 Sevilla, Spain

The combustion of crude oil produces a wide range of pollutants, including gases, volatile organic compounds, polycyclic aromatic hydrocarbons, acid compounds (e.g., sulfuric acid), and soot. Several of these pollutants have been linked with the deterioration and blackening of monuments. The paper reports the results of an investigation on the causes of the soiling of cultural remains at important archaeological sites in the provinces of Khuzestan and Fars, in southern Iran, assumed to be an effect of the Persian Gulf oil well fires of 1991. Different analytical techniques were applied to characterize the mineralogical composition of the damage layers, investigate the deposition of atmospheric particles, measure the anion concentrations, and identify and quantify the carbon components. The results showed that the black deposits on the surfaces of the Iranian monuments considered are mainly microbiotic crusts produced by cyanobacterial growth. No evidence was found of the deposition of particulate matter (smoke) produced by the Kuwait oil fires during the Gulf War.

\section{Introduction}

During the Gulf War, the environments of Kuwait and neighboring countries were affected by the oil well fires that burned for months, releasing contaminants into the atmosphere. As the Iraqi forces withdrew from Kuwait, they had set fire to over half of its 1000 oil wells and damaged most of the rest. The $\mathrm{Al}$ Burqan oil field, with approximately 700 wells (of which 365 were ignited), was the biggest and most important field in terms of oil production, number of wells set on fire, and amount of smoke generated (1). During the fires, it was estimated that 5-6 million barrels of crude oil and 70-100 million $\mathrm{m}^{3}$ of natural gas were burned per day.

The combustion of crude oil produces a wide range of pollutants, including gases, volatile organic compounds, polycyclic aromatic hydrocarbons, acid compounds (e.g., sulfuric acid), and soot (organic and elemental carbon). In

* Corresponding author phone: +39-051-6399571; fax: +39-0516399649; e-mail: a.bonazza@isac.cnr.it.

$\dagger$ CNR.

‡ University of Bologna.

$\S$ CSIC.
Kuwait and neighboring regions, the concentrations of volatile organic compounds, polycyclic aromatic compounds, metals, and other pollutants subsequently turned out to be much lower than initially presumed, considering the magnitude of the fires $(2,3)$. The intensity of the fires made combustion relatively efficient, with about $96 \%$ of the burned carbon emitted as $\mathrm{CO}_{2}$, and very low emissions of $\mathrm{CO}$ and soot. Although particulate concentrations were much higher, this was ultimately considered not to be the result of the oil fires, but rather, a characteristic of the region itself. In fact, a comparison of measurements taken in 1991 and 1994, after the fires had long been extinguished, showed similar average values (4).

Shirazi et al. (5) reported that the fall out of the ensuing smoke plumes reached as far as the center of Iran and the Persian Gulf region in the form of wet/dry precipitation. The coverage area of the plume extended over eight southern Iranian provinces, which are home to a number of major archaeological sites and museum collections. According to Shirazi et al. (5), during and after the event, many black/ acidic rains were reported in these provinces, while other studies focused on the mechanisms and impacts of dry deposition. These authors suggested that visible evidence of changes and negative effects on cultural heritage was present.

The Iranian authorities claimed that the cultural heritage in some provinces had been severely damaged by the smoke produced by the fires. The United Nations Compensation Commission agreed that the smoke from the oil well fires had reached Iran. The United Nations issued its final report on compensation for the environmental and public health damage resulting from Iraq's 1990-1991 invasion and occupation of Kuwait. However, no compensation for Iran's claim for damage to cultural heritage was awarded, due to insufficient evidence concerning the nature and extent of damage and the contribution of other factors, such as local sources of pollution from motor vehicle emissions, regional oil refining, and the human occupation of historic sites (6).

The numerous studies reported in the literature on damage affecting monuments located in urban areas with high air pollution have demonstrated that the main deterioration process is black crust formation (7-9). Black crusts are observed mainly on carbonate stone surfaces wetted by rainwater but sheltered from intensive runoff and wash out. They are due to the dry and wet deposition of $\mathrm{SO}_{2}$ and carbon particles. The reaction of $\mathrm{SO}_{2}$ with the carbonate material leads to the formation of gypsum (i.e., calcium sulfate dihydrate) through the well-studied sulfation process, while the black component of carbonaceous aerosol is recognized to be responsible for soiling and blackening, with the ensuing aesthetic damage on monument surfaces $(9,10)$. However, the black color on some monument surfaces could have a biological origin (11).

The present paper focuses on the causes of the blackening and soiling encountered on the monument surfaces and basreliefs at important Iranian archaeological sites, located in the southern provinces of Khuzestan and Fars, which are claimed to have been affected by the oil well fires in the 1991 Gulf War.

\section{Experimental Section}

Sampling. A sampling campaign was carried out between 11 and 18 September 2003 to investigate in detail the southern Iranian archaeological sites in Khuzestan and Fars provinces. The two provinces have a large number of archaeological sites and a wide range of remains in the form of stone buildings, bas-reliefs, and carvings. The bas-reliefs and stone 


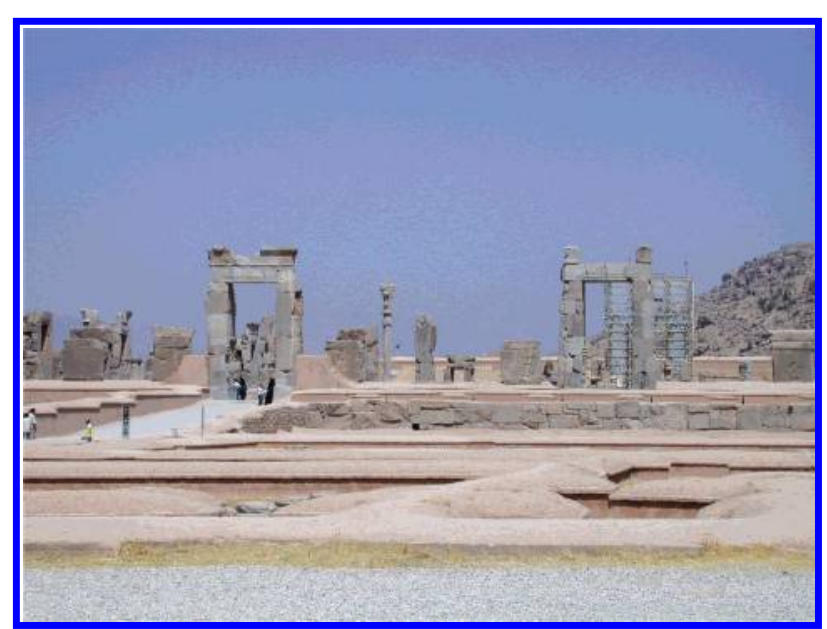

FIGURE 1. View of the Persepolis Complex in Fars province (Iran).

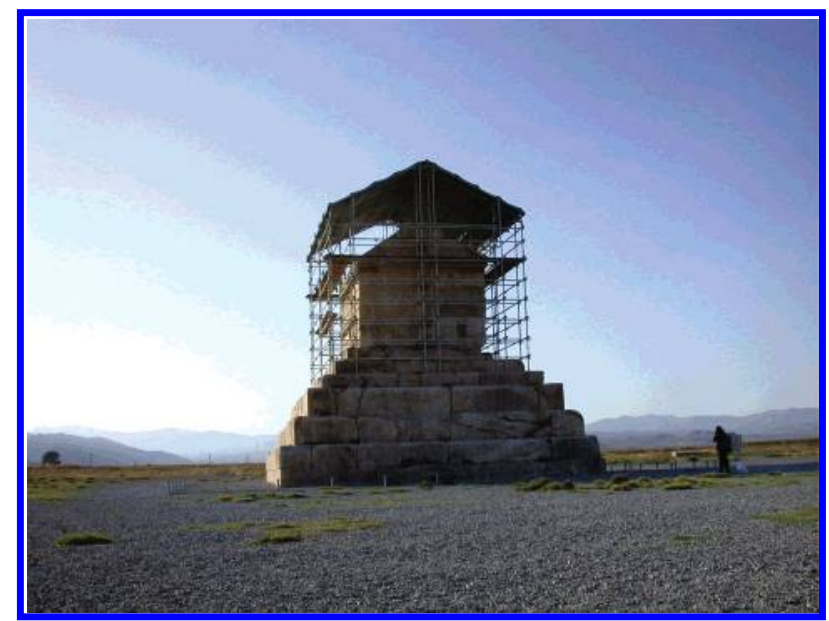

FIGURE 2. Tomb of Cyrus in the Pasargadae Complex in Fars province (Iran).

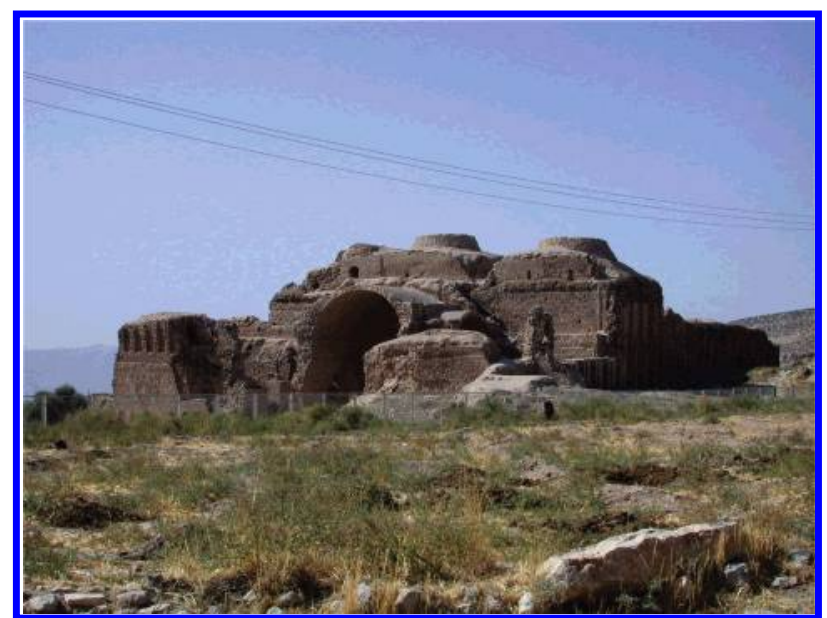

FIGURE 3. Sassanian Fire Temple at Firooz Abad in Fars province (Iran).

surfaces at the sites presented areas of black stains and unstained stone. Samples of surface deposits and damage layers were collected from the Persepolis Complex (Figure 1), Pasargadae Complex (Figure 2), Sassanian Fire Temple and Dokhtar Castle at Firooz Abad (Figure 3), as well as the Shapour bas-reliefs at Bishapour (Figure 4), all in Fars province. In Khuzestan, samples were collected from the Izeh bas-reliefs (Figure 5) and the Palace of Darius in Susa (Figure 6). Only the sampling site of Susa has the typical features of an urban location, while the other archaeological

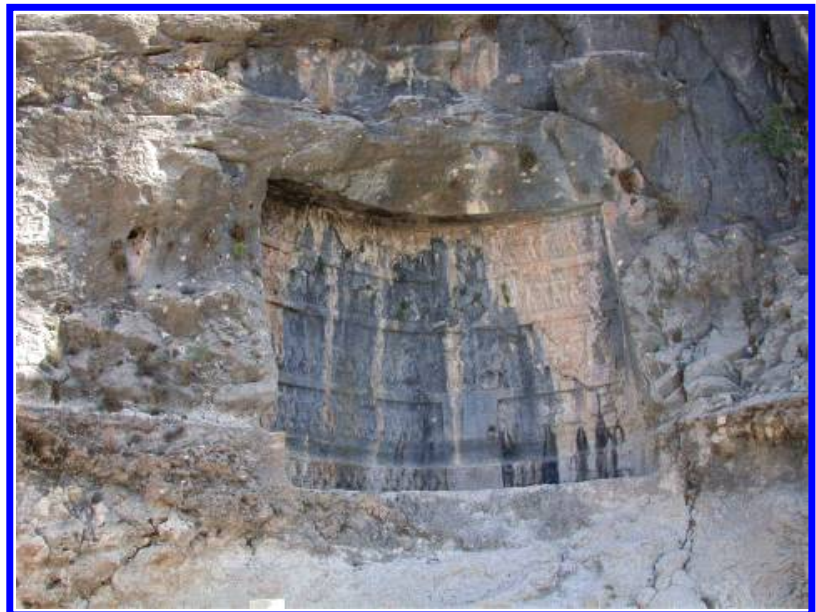

FIGURE 4. Shapour bas-relief showing the victory of Bishapour over Valerian, in Fars (Iran).

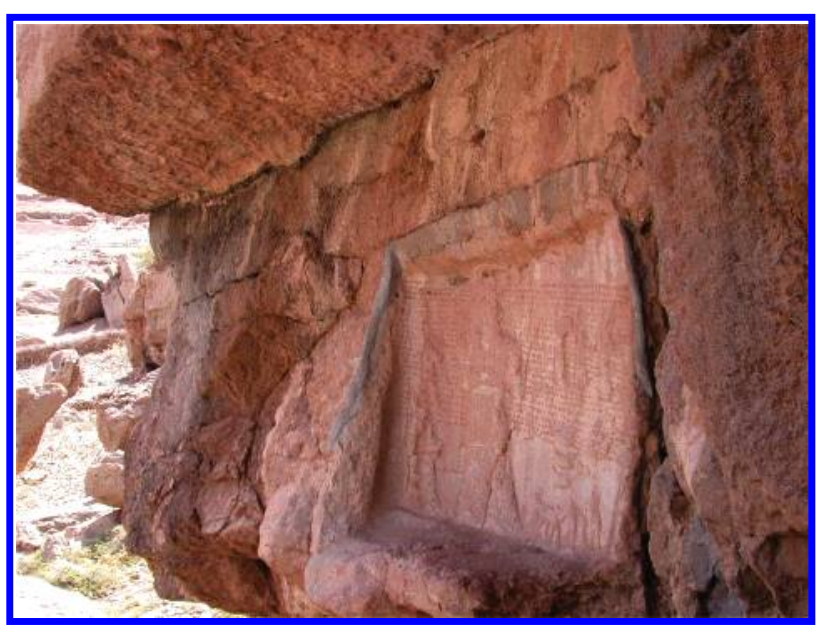

FIGURE 5. Izeh bas-relief $n^{\circ} 1$ in Khuzestan province (Iran).

remains studied are situated far from city centers or polluted areas.

On visual inspection most of the archaeological sites appeared to be clearly damaged by soiling and blackening, particularly the Shapour bas-reliefs. Furthermore, evident signs of biodeterioration were encountered.

Since one of the main objectives of the present work was to understand the cause of soiling and blackening, sampling focused on surfaces that were sheltered and had not undergone cleaning or previous restoration work to obtain representative specimens of the damage process under study. In addition, for the purpose of characterizing the original materials, samples of underlying stone were also collected. The specimens took the form of (a) incoherent material scraped away using a scalpel as far as possible limiting the removal of undamaged stone, (b) fragments with the copresence of black deposit and undamaged stone, and (c) fragments of visually undamaged stone. The number of samples and the amount of each specimen were strictly linked to the possibility of sampling without causing damage to the archaeological remains under study. The specimens on which the investigation of soiling and blackening was performed are listed in Table 1.

Inorganic Analyses. After collection, the samples were dried and stored at $20^{\circ} \mathrm{C}$ in a nitrogen environment, until the time of analysis. First, the mineralogical features of the surface deposit and the substrate material were identified by optical microscopy $(\mathrm{OM})$ observations of thin transversal sections, using an Olympus BX51 and X-ray diffraction (XRD) analyses with a Philips PW 1730. To identify any atmospheric carbon- 


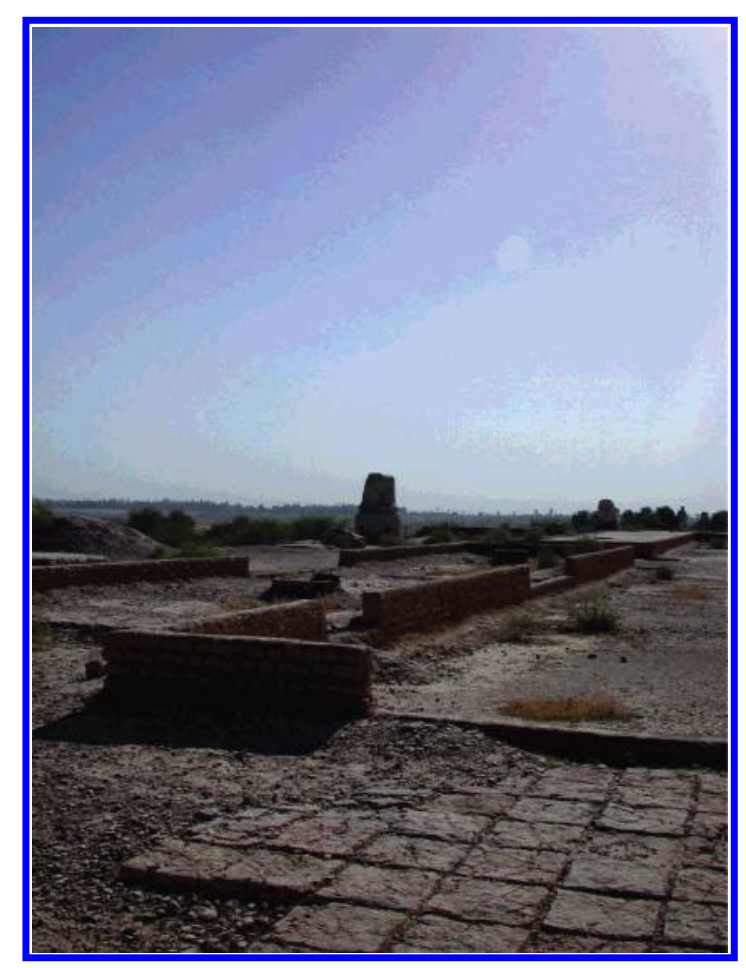

FIGURE 6. Archaeological remains of the Palace of Darius in Susa, Khuzestan (Iran).

aceous particles deposited on the surface, scanning electron microscope observations were carried out using a Philips XL 20 equipped with a dispersive energy analyzer (SEM-EDX). The thermal behavior of the samples was evaluated by means of differential and gravimetric thermal analysis (DTA-TGA) using a Mettler Toledo TGA/SDTA 851. Ion chromatographic analyses were performed using a Dionex Chromatograph (4500i model). Subsequently, to discriminate and quantify the carbon species in the damage layers, the powder specimens underwent an analytical methodology specifically set up for carbon measurement (12). In this case, for non carbonate carbon (NCC) quantification, samples were placed in silver capsules, subjected to two repeated steps of acidification with $\mathrm{HCl}$ concentrate solution to remove carbonates, and then fully oxidized to quantify the carbon content by flash combustion/gas chromatographic analysis using a commercial carbon-hydrogen-nitrogen-sulfur-oxygen (CHNSO EA 1108 FISONS Instruments) analyzer.

Organic Analyses. Alkaline hydrolysis of samples and analysis of fatty acids were performed as described by Gugger et al. (13). Thermally assisted hydrolysis and methylation (thermochemolysis) and gas chromatography-mass spectrometry were performed following Saiz-Jimenez (14). Briefly, a few mg of sample were deposited in a Curie-point small hollow ferromagnetic cylinder (temperature $500{ }^{\circ} \mathrm{C}$ ) and wetted with $5 \mu \mathrm{L}$ of a $25 \% \mathrm{w} / \mathrm{w}$ methanolic solution of tetramethyl ammonium hydroxide (TMAH). The cylinder was lightly dried with an $\mathrm{N}_{2}$ flow and immediately inserted in the pyrolyser. The analysis was carried out in a Fisons instrument GC 8000/MD 800, using a $30 \mathrm{~m} \times 0.25 \mathrm{~mm}$ TRB-5HT column (film thickness $0.1 \mu \mathrm{m}$ ), coupled with a Fischer 0316 Curiepoint pyrolyser. The GC oven was programmed from 50 to $280{ }^{\circ} \mathrm{C}$, at a rate of $5{ }^{\circ} \mathrm{C} \mathrm{min}^{-1}$. This temperature was held for $100 \mathrm{~min}$ and then increased to $310^{\circ} \mathrm{C}$ at a rate of $20^{\circ} \mathrm{C}$ $\mathrm{min}^{-1}$, and the final temperature was held for $2 \mathrm{~min}$. In the analytical procedure adopted here, carboxylic acids were recovered as the corresponding methyl esters, and hydroxyls as methoxyls. No attempt was made to identify the high number of evolved compounds, but only the most abundant or representative ones (e.g., molecular markers).
Molecular Analyses. DNA was extracted from black deposit samples using the NucleoSpin Food DNA extraction kit (Mackerey-Nagel, Düren, Germany). Amplification of $16 \mathrm{~S}$ and 18S rRNA gene sequences was performed by PCR using the Cyanobacteria-specific primer pair, Cya106F and Cya781R (15). Eukarya-specific primers, EukA and EukB (16), were also assayed during this study. Amplification by PCR was performed in the following thermal conditions: $95{ }^{\circ} \mathrm{C}$ for $2 \mathrm{~min}$; 35 cycles of $95{ }^{\circ} \mathrm{C}$ for $15 \mathrm{~s}, 60^{\circ} \mathrm{C}$ for $15 \mathrm{~s}\left(55^{\circ} \mathrm{C}\right.$ for Eukarya-specific primers), $72^{\circ} \mathrm{C}$ for $1 \mathrm{~min}$ ( 2 min for Eukaryaspecific primers), and a final step of $72{ }^{\circ} \mathrm{C}$ for $10 \mathrm{~min}$. DNA libraries of PCR amplified products were constructed using the TOPO-TA cloning kit (Invitrogen, Carlsbad, California), according to the manufacturer recommendations. Clone screening was carried out following the method described by Gonzalez et al. (17) using denaturing gradient gel electrophoresis. Homology searches for the retrieved sequences were performed using the Blast algorithm at the National Center for Biotechnology Information (NCBI; http:// www.ncbi.nlm.nih.gov/BLAST).

\section{Results and Discussion}

\section{Inorganic Fraction Analyses}

With the exception of the historic complexes of Susa, all the investigated sites were characterized by surface blackening and soiling, easily observable on visual assessment during the sampling campaign. In addition, most sites revealed evident signs of biological weathering, especially the Complexes of Persepolis and Pasargadae (PER 3, PAS 2), the archaeological sites at Firooz Abad (FIR 9 and 10) and the bas-reliefs in Fars province (BIS 1 and 2).

With regard to weathering processes, the processing of the results obtained through the adopted analytical procedure, allowed the identification of the damage typologies affecting the monument surfaces under consideration.

The petrographical characterization performed by optical microscopy indicated that the original building materials collected from all the monuments investigated are metamorphic and sedimentary carbonate stones, mainly composed of calcite and dolomite. Almost all the samples revealed the presence of a red-brown colored surface layer, mainly consisting of secondary calcite and dolomite, quartz, sheet silicates, and oxides and hydroxides of iron (Figure 7). None of the observed samples showed any evidence of black particles linked to combustion processes embedded in the damage layers. X-ray diffraction analysis confirmed and integrated the mineralogical composition of the surface deposits revealed by OM analysis (Table 2). Only in one case (sample FIR 7, Sassanian Fire Temple at Firooz Abad) was an abundance of gypsum identified.

Garcia-Valles et al. (18) explained the formation of redorange patinas on Mediterranean monuments as the result of bioactivity and the presence of iron oxides. The presence of iron oxides on the external surface of the samples can also be interpreted as evidence of a dedolomitization process occurring in oxidizing conditions, during which any ferrous iron in the precursor dolomite is oxidized to produce iron oxides.

Scanning electron microscope analysis highlighted, in all samples, a high degree of surface inter-crystalline decohesion, due to wind erosion produced by the impact of airborne soil dust, and biological colonization (Figure 8). Aluminosilicate and carbonaceous particles, due to fuel combustion processes, were not identified.

Ghedini et al. (19) demonstrate that the total carbon (TC) content in black layers is composed of two main fractions: carbonate (CC) and non carbonate carbon (NCC), the latter comprising an organic (OC) and elemental (EC) fraction.

As the chemical-thermal analysis for carbon fraction speciation and measurement requires about $1 \mathrm{~g}$ of material 


\begin{tabular}{|c|c|c|c|}
\hline sample & site & sampling point & description \\
\hline PER 3 & $\begin{array}{l}\text { Persepolis Complex, } \\
\text { Persepolis }\end{array}$ & $\begin{array}{l}\text { left-hand corner of a niche, } 2.50 \mathrm{~m} \text { from the ground, } \\
\text { in the western wall of the Hundred Columns Hall }\end{array}$ & black deposit \\
\hline PAS 2 & $\begin{array}{l}\text { Cyrus Tomb, } \\
\text { Pasargadae Complex }\end{array}$ & $\begin{array}{l}\text { south side of the base, } \\
\text { about } 3.00 \mathrm{~m} \text { from ground }\end{array}$ & $\begin{array}{l}\text { black surface deposit and fragment, } \\
\text { with co-presence of deposit and } \\
\text { stone substrate }\end{array}$ \\
\hline FIR 7 & $\begin{array}{l}\text { Sassanian Fire Temple, } \\
\text { Firooz Abad }\end{array}$ & west-facing wall about $1.60 \mathrm{~m}$ from ground & stone fragment with black layer \\
\hline FIR 9 & $\begin{array}{l}\text { Dokhtar Castle, } \\
\quad \text { Firooz Abad }\end{array}$ & $\begin{array}{l}\text { mound of collapsed building materials, } \\
\text { collected at about } 7.00 \mathrm{~m} \text { from base }\end{array}$ & fragment of material with black deposit \\
\hline FIR 10 & $\begin{array}{l}\text { Dokhtar Castle, } \\
\text { Firooz Abad }\end{array}$ & $\begin{array}{l}\text { natural outcrop halfway up the hill slope } \\
\text { to the fortress }\end{array}$ & $\begin{array}{l}\text { fragment of incoherent material } \\
\text { with dark deposit }\end{array}$ \\
\hline BIS 1 & $\begin{array}{l}\text { Shapour bas-reliefs, } \\
\text { Bishapour }\end{array}$ & first bas-relief, $1.30 \mathrm{~m}$ from base & black deposit \\
\hline BIS 2 & $\begin{array}{l}\text { Shapour bas-reliefs, } \\
\text { Bishapour }\end{array}$ & $\begin{array}{l}\text { first bas-relief, } 0.50 \mathrm{~m} \text { from base, } \\
\text { below sample BIS } 1\end{array}$ & black deposit \\
\hline EEZ 3 & $\begin{array}{l}\text { Izeh bas-reliefs, } \\
\text { Izeh }\end{array}$ & bas-relief $n^{\circ} 2$ & surface fragment \\
\hline EEZ 4B & $\begin{array}{l}\text { Izeh bas-reliefs, } \\
\text { Izeh }\end{array}$ & bas-relief $n^{\circ} 1$ & black deposit \\
\hline SUS 2 & $\begin{array}{l}\text { Palace of Darius, } \\
\text { Susa }\end{array}$ & column base & surface fragment \\
\hline
\end{tabular}

\section{TABLE 2. Main Mineralogical Phases Revealed by X-ray Diffraction in the Analyzed Damage Layers ${ }^{a}$}

$\begin{array}{lllccc}\text { sample } & \text { calcite } & \text { quartz } & \text { dolomite } & \text { gypsum } & \text { ankerite } \\ \text { PER 3 } & ++++ & ++ & - & - & - \\ \text { PAS 2 } & ++++ & ++ & ++++ & - & +++ \\ \text { FIR 7 } & ++++ & \text { traces } & + & ++ & - \\ \text { BIS 1 } & ++++ & + & - & - & - \\ \text { EEZ 4B } & ++++ & \text { traces } & - & - & - \\ \text { SUS 2 } & ++++ & \text { traces } & - & - & - \\ \text { a }++++ \\ + \text { present,- absent. }\end{array}$

to perform a complete procedure, it was not possible to sample a sufficient amount of soiling deposit from the Iranian sites. Therefore, the non carbonate carbon was measured, without speciation in OC and EC. The NCC data of representative specimens of Persepolis (PER 3), Pasargadae (PAS 2), Shapour (BIS 2) and Izeh bas-reliefs (EEZ 4B) are shown in Table 3.

The NCC fraction is the carbon component that is not linked to the carbonate substrate, but originates from biological weathering (11) and anthropogenic activities (9, 12 , 19). The latter includes the deposition atmospheric particles containing elemental and organic carbon, of primary and secondary origin (20) as well as the decay of past surface treatments (oils, waxes, proteins, etc.) applied to the monuments to protect them (21).

In the Iranian specimens analyzed, the NCC fraction is present in concentrations varying from $0.20 \%$ in sample EEZ 4B (Izeh bas-reliefs) to $11.56 \%$ in sample PER 3 (Persepolis). As the sampling focused on surfaces that had never undergone restoration, the decay of organic treatments can be excluded as a possible origin of organic carbon.

The differential (DTA) and gravimetric thermal analysis (TGA) evidenced the same thermal behavior in samples PER 3, PAS 2, BIS 1, and EEZ 4B, with the presence of two exothermic peaks within the DTA curve corresponding to the first two steps of loss of weight (Table 4). The first peak occurs in the temperature range between 323 and $341{ }^{\circ} \mathrm{C}$, while the second is located between 450 and $484^{\circ} \mathrm{C}$. Both peaks are correlated with $\mathrm{CO}_{2}$ development due to carbon component oxidation. According to studies on the thermal behavior of organic compounds in atmospheric aerosols, the thermal peaks attributed to volatile primary and second- ary organics occur before $350{ }^{\circ} \mathrm{C}$. The peak at around $350{ }^{\circ} \mathrm{C}$ under oxygen corresponds to the evolution of a dark (gray) component, attributed to black carbon (also referred to as soot) (20). Thus, in the analysis of black sulfated crusts from urban monuments $(12,19)$, the first peak is certainly related to organic carbon, while the second peak can be attributed

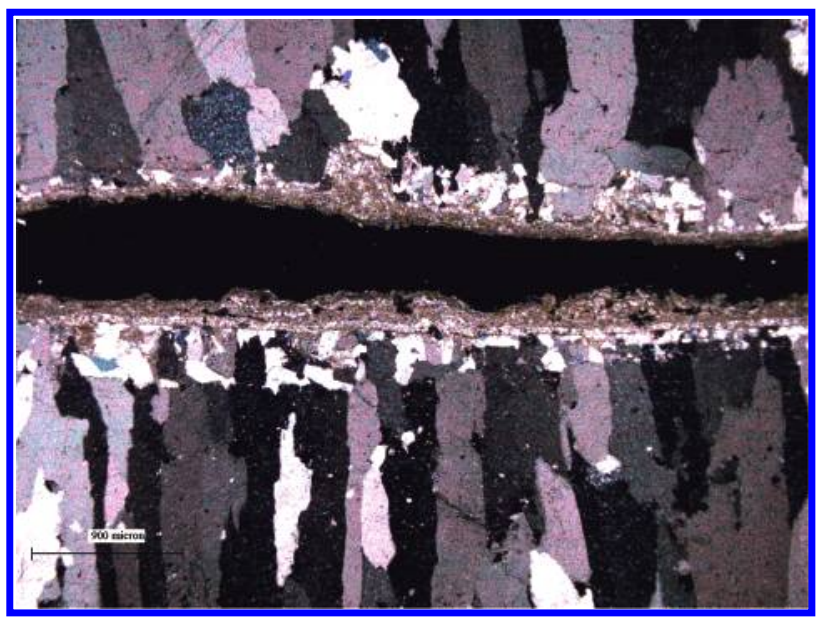

FIGURE 7. Optical micrograph (crossed polars) showing two fragments of carbonate substrate and the overlying red-brown colored surface layer.

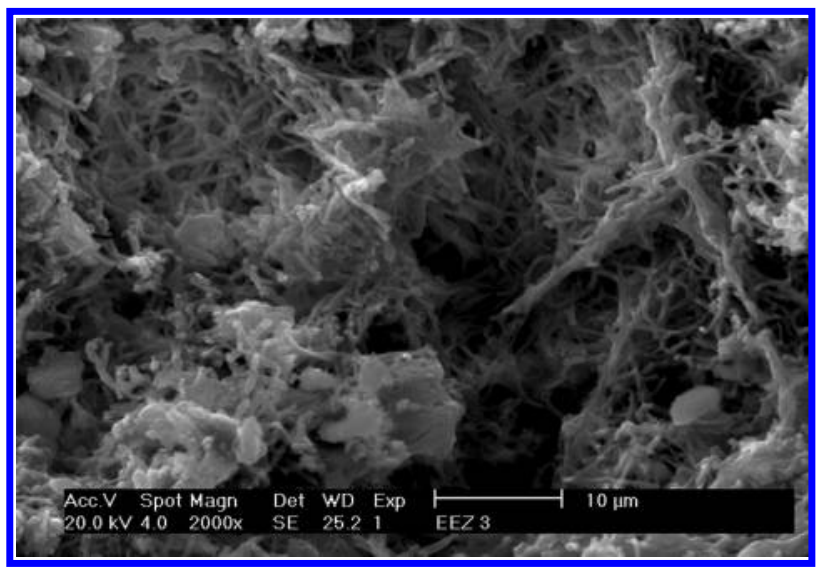

FIGURE 8. Scanning electron micrograph showing biological colonization at the sample surface on the Izeh bas-reliefs. 


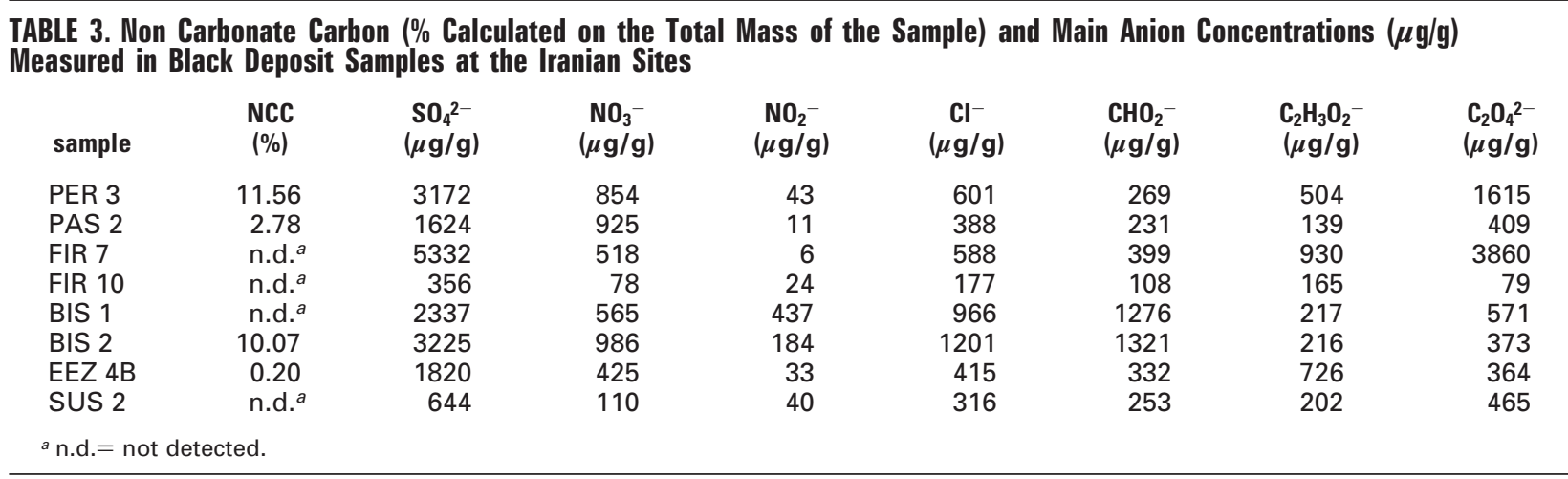

TABLE 4. Results of the DTA-TGA Analyses ${ }^{a}$

\begin{tabular}{|c|c|c|c|c|c|}
\hline sample & $\begin{array}{l}\text { exothermic/endothermic } \\
\text { reaction }\end{array}$ & $\begin{array}{c}\text { gypsum } \\
\text { dehydration }\end{array}$ & $\begin{array}{l}\text { carbon compound } \\
\text { thermal reactions }\end{array}$ & $\begin{array}{l}\text { carbon compound } \\
\text { thermal reactions }\end{array}$ & $\begin{array}{l}\text { decarbonation } \\
\text { reactions }\end{array}$ \\
\hline \multirow{2}{*}{ PER 3} & Temperature peak $\left({ }^{\circ} \mathrm{C}\right)$ & & 326 & 456 & 749 \\
\hline & Weight loss $(\%)$ & & 25.4 & 18.9 & 14.3 \\
\hline \multirow{2}{*}{ PAS 2} & Temperature peak $\left({ }^{\circ} \mathrm{C}\right)$ & & 323 & 454 & 815 \\
\hline & Weight loss (\%) & & 9.2 & 5.9 & 31.9 \\
\hline \multirow{2}{*}{ FIR 7} & Temperature peak $\left({ }^{\circ} \mathrm{C}\right)$ & 131 & & & 829 \\
\hline & Weight loss (\%) & 1.6 & 38.2 & & \\
\hline \multirow{2}{*}{ BIS 1} & Temperature peak $\left({ }^{\circ} \mathrm{C}\right)$ & & 324 & 450 & 804 \\
\hline & Weight loss $(\%)$ & & 14.4 & 6.4 & 29.3 \\
\hline \multirow{2}{*}{ EEZ 4B } & Temperature peak $\left({ }^{\circ} \mathrm{C}\right)$ & & 341 & 484 & 835 \\
\hline & Weight loss (\%) & & 2.9 & 1.2 & 38.1 \\
\hline \multirow{2}{*}{ SUS 2} & Temperature peak $\left({ }^{\circ} \mathrm{C}\right)$ & & & & 836 \\
\hline & Weight loss (\%) & & & & 43.1 \\
\hline
\end{tabular}

to elemental carbon, which is known to be a tracer of particles emitted into the atmosphere by combustion processes (12). However, in biological samples, the refractory biopolymers highly resistant to drastic chemical treatments, upon pyrolysis at $400{ }^{\circ} \mathrm{C}$ yielded up to $46 \%$ of a highly aromatic insoluble residue (22), which could account for the observed peak around $450^{\circ} \mathrm{C}$. In samples FIR 7 and SUS 2, the peaks relating to carbon fraction oxidation are not recognizable. Sample FIR 7 presents a temperature peak at $131{ }^{\circ} \mathrm{C}$ related to gypsum dehydration, confirming the results obtained by XRD analysis. Finally, all samples show an endothermic peak in correspondence to the third loss of weight at $749-837^{\circ} \mathrm{C}$ due to carbonate decomposition.

The data obtained through the application of IC technique on the samples collected (Table 3) indicate that sulfates are the most abundant anions in the samples analyzed, with concentrations varying between $356 \mu \mathrm{g} / \mathrm{g}$ (FIR 10) and 5332 $\mu \mathrm{g} / \mathrm{g}$ (FIR 7). The origin of the sulfate is uncertain. It could be that the Iranian monument surfaces were, at some time, affected by anthropogenic depositions. However, a more likely origin is wind dispersion, since Iran is one of the world's largest producers of gypsum, with 345 mines, 11 of which are in Khuzestan and 8 in Fars province (2 in Firooz Abad), and gypsiferous soils are common in Iranian arid and semiarid areas (23). In any case, these sulfate concentrations are much lower than those normally encountered in black crusts on monuments located in European cities (52-542 $\times 10^{3}$ $\mu \mathrm{g} / \mathrm{g})(24)$.

The presence of short-chain organic anions, such as oxalate, formate, and acetate, listed in order of abundance, was also revealed. Although it is widely accepted that these anions can also originate from atmospheric deposition, mainly as organic pollutants of secondary formation (25), their biological origin is unquestioned, especially as far as oxalates are concerned (26).

Smaller and variable quantities of $\mathrm{NO}_{3}{ }^{-}$ions, ranging from $78 \mu \mathrm{g} / \mathrm{g}$ (FIR 10) to $986 \mu \mathrm{g} / \mathrm{g}$ (BIS 2), and $\mathrm{NO}_{2}{ }^{-}$, from $6 \mu \mathrm{g} / \mathrm{g}$
(FIR 7) to $437 \mu \mathrm{g} / \mathrm{g}$ (BIS 1), were found. In general, nitrogen acids interact with the calcium of the stone to form highly soluble salts (nitrate and nitrite), and the relatively large amount detected in this study compared to those generally measured in black crusts in U.S. and European rural sites (24) can be related to the scarce episodes of seasonal runoff. A similar consideration can be extended to $\mathrm{Cl}^{-}$, detected in significant concentrations. Finally, the ions $\mathrm{F}^{-}, \mathrm{Br}^{-}$, and $\mathrm{HPO}_{4}=$ were found to be present in very small amounts.

Intercrystalline decohesion, due to wind erosion, surface oxidation, and blackening are the main damage typologies encountered at the Iranian archaeological sites under study. With regard to soiling and blackening in polluted urban environments $(7,8,19)$, damage layers are an integral product of the deposition onto stones, whose surfaces experience exposure to atmospheric impacts over long periods of time. However, the effect of an episodic event, such as the oil well fires in the Gulf War, was not observed in the studied samples.

Organic Fraction Analyses. TMAH thermochemolysis was used to study macromolecules $(11,27)$. Figure 9 shows the results from TMAH thermochemolysis, followed by GC-MS analysis of the Iranian black layers. The listed samples are from Pasargadae (PAS 2) (Figure 9 A), Dokhtar Castle (FIR 10) (Figure 9 B), Persepolis (PER 3) (Figure 9 C) and the Izeh bas-reliefs (EEZ 4B) (Figure 9 D). Some of the most abundant TMAH products are listed in Table 5 . The organic fraction of the black layers from all the Iranian monuments investigated, as revealed by thermochemolysis, predominantly contained fatty acids, a high percentage of which took the form of polyunsaturated fatty acids, and a prevalence of $n$-heptadecane over other $n$-alkanes. $n$-Heptadecane is a typical marker of cyanobacteria (28), and was present in all the chromatograms. Similar patterns were previously found in the black stains from the Caestia pyramid in Rome, Italy (11), and in a black coating formed by the cyanobacterium Scytonema sp. on limestone walls in Jerusalem, Israel (28). 


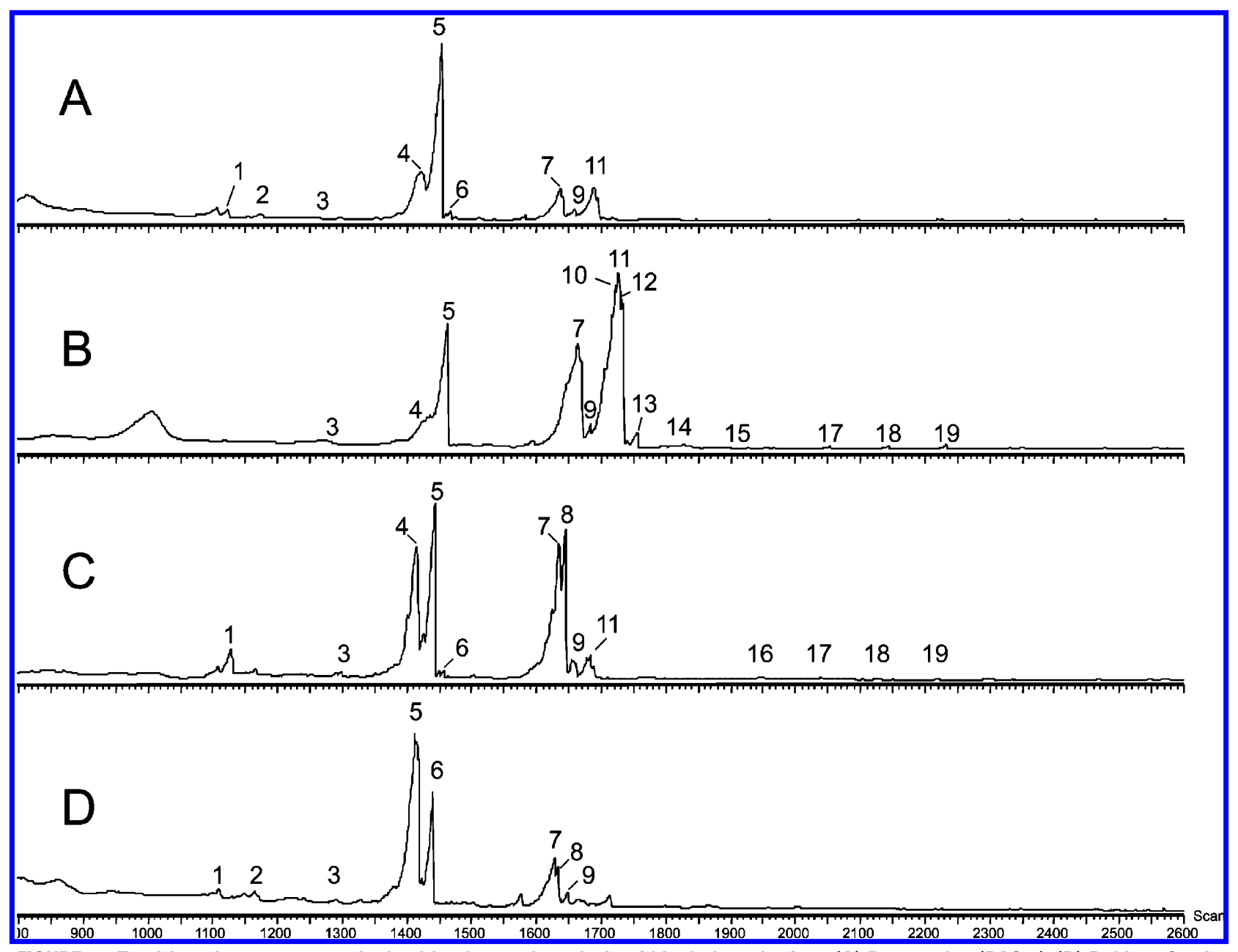

FIGURE 9. Total ion chromatograms obtained by thermochemolysis of black deposits from (A) Pasagardae (PAS 2), (B) Dokhtar Castle (FIR 10), (C) Persepolis (PER 3), and (D) Izeh bas-reliefs (EEZ 4B). Peaks refer to Table 5.

TABLE 5. Major Compounds Identified in the Black Deposits from (A) Pasargadae Complex (PAS 2), (B) Dokhtar Castle (FIR 10), (C) Persepolis Complex (PER 3), and (D) Izeh Bas-Reliefs (EEZ 4B) ${ }^{a}$

\begin{tabular}{cl} 
peak & \multicolumn{1}{c}{ compound } \\
1 & $n$-heptadecane \\
2 & $n$-tetradecanoic acid methyl ester \\
3 & $n$-pentadecanoic acid methyl ester \\
4 & methyl pentadecanoic acid methyl ester \\
5 & $n$-hexadecanoic acid methyl ester \\
6 & hexadecadienoic acid methyl ester \\
7 & octadecenoic acid methyl ester \\
8 & cis-9-octadecenoic acid methyl ester \\
9 & n-octadecanoic acid methyl ester \\
10 & octadecadienoic acid methyl ester \\
11 & octadecadienoic acid methyl ester \\
12 & octadecadienoic acid methyl ester \\
13 & octadecadienoic acid methyl ester \\
14 & $n$-nonadecanoic acid methyl ester \\
15 & $n$-eicosanoic acid methyl ester \\
16 & $n$-heneicosanoic acid methyl ester \\
17 & $n$-docosanoic acid methyl ester \\
18 & $n$-tricosanoic acid methyl ester \\
19 & $n$-tetracosanoic acid methyl ester
\end{tabular}

${ }^{a} A, B, C$, and D refer to total ion chromatograms reported in Figure 9.

The considerable amount of lipids and the high degree of unsaturation observed in the fatty acids is typical of phototrophic microorganisms, which have been proved to accumulate lipids.
Alkaline hydrolysis of black deposits and identification of fatty acids was also carried out. This is a method originally developed for the analysis of whole microbial cells and used for microbial community structure analysis and chemotaxonomic studies (29). A total of 29 fatty acids were identified using a standard library containing 104 fatty acids (30). Identifications were reconfirmed by gas chromatographymass spectrometry in a representative sample (FIR 9) as shown in Figure $10 \mathrm{~A}$.

A detailed analysis of the sample FIR 9 from Dokhtar Castle at Firooz Abad (Figure 10 B, Table 6) in the scan range of 1200-1850 permitted the comparison of the $\mathrm{C}_{14}-\mathrm{C}_{18}$ fatty acids obtained using alkaline hydrolysis and thermochemolysis. Both chromatograms showed similar fatty acid distributions, but the thermochemolysis chromatogram revealed some unsaturated fatty acids (16:2 and 18:2) that were absent in alkaline hydrolysis. The production of additional peaks of 16:2 and 18:2 resulted from the thermal isomerization of unsaturated fatty acids in the presence of TMAH, which is commonly observed, as an unwanted side-reaction, in thermochemolysates (31).

In addition, the presence of pristenes, phytenes, phytadienes, and phytol was revealed. The isoprenoids phytane and pristane are normal constituents of cyanobacterial species (28), and pristenes, phytenes, and phytadienes are their pyrolysis products (32). Phytol is the isoprenoid alcohol bound to chlorophyll, which is effectively released by thermochemolysis. This is a further indication of the presence of phototrophic microorganisms in the analyzed samples. 


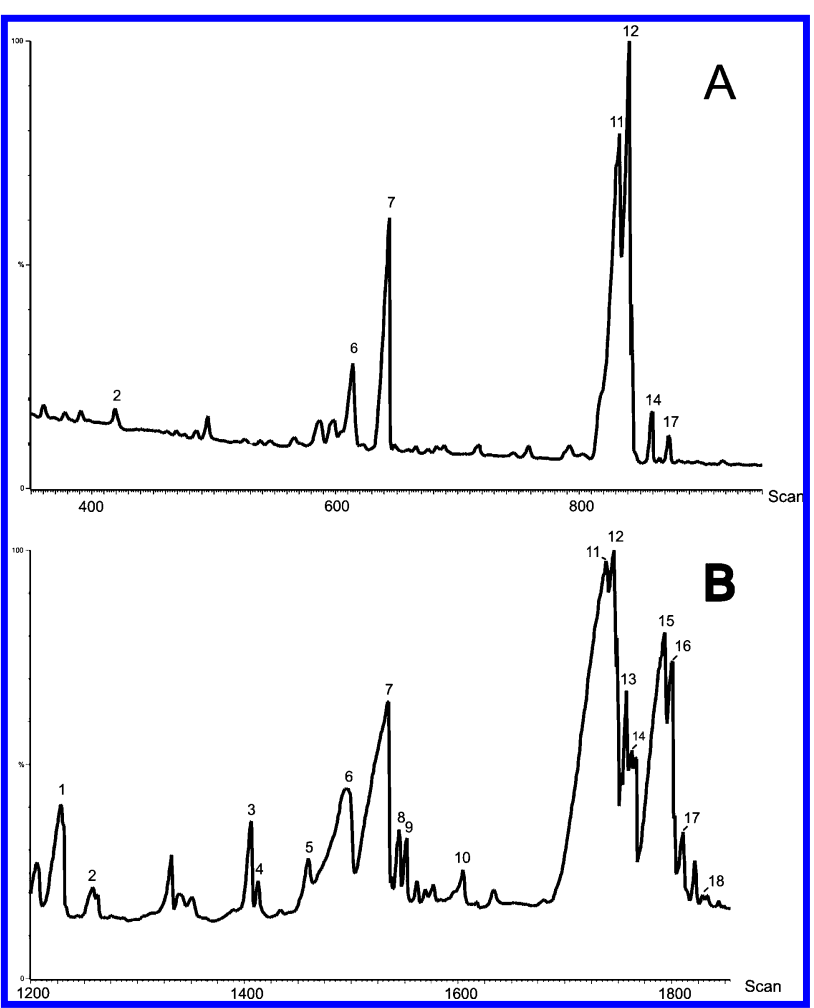

FIGURE 10. Total ion chromatograms obtained by alkaline hydrolysis (A) and thermochemolysis (B) from Dokhtar Castle black deposits (FIR 9)

TABLE 6. Major Compounds Identified in the Black Deposits from Alkaline Hydrolysis (A) and Thermochemolysis (B) from Dokhtar Castle (FIR g) ${ }^{a}$

\begin{tabular}{rl} 
peak & \multicolumn{1}{c}{ compound } \\
1 & $n$-heptadecane \\
2 & $n$-tetradecanoic acid methyl ester \\
3 & phytadiene \\
4 & phytene \\
5 & phytadiene \\
6 & 9-hexadecenoic acid methyl ester \\
7 & $n$-hexadecanoic acid methyl ester \\
8 & hexadecadienoic acid methyl ester \\
9 & hexadecadienoic acid methyl ester \\
10 & 9,10 -methylenehexadecanoic acid methyl ester \\
11 & octadecadienoic acid methyl ester \\
12 & cis-9-octadecenoic acid methyl ester \\
13 & phytol \\
14 & $n$-octadecanoic acid methyl ester \\
15 & octadecadienoic acid methyl ester \\
16 & octadecadienoic acid methyl ester \\
17 & octadecatrienoic acid methyl ester \\
18 & 9,10 -methyleneoctadecanoic acid methyl ester \\
a Peaks refers to chromatograms reported in Figure 10.
\end{tabular}

Other compounds found in the chromatogram of Dokhtar Castle are worthy of comment, such as the cyclopropyl (cy 17:0 and cy 19:0), fatty acids (Table 6), and methylalkanes (minor peaks not shown in Figure 10 B) $(33,34)$. Gramnegative, anaerobic bacteria contain cyclopropyl fatty acids. However, these fatty acids are not exclusive to this group and occur quite widely in many bacterial genera, including cyanobacteria (33). The presence of methylalkanes is further evidence of cyanobacteria (34).

All cyanobacteria synthesize alkanes, but the amounts are often small in comparison with other lipid classes, such as fatty acids, except for some Nostoc sp. where the content of $n$-alkanes was comparable to that of fatty acids (35). When using high-resolution SIM-mode $(\mathrm{m} / z 99)$, it was only possible to observe a definite $n$-alkanes pattern from $\mathrm{C}_{22}-\mathrm{C}_{34}$ in the sample BIS 1 from Shapour, similar to that reported for Nostoc sp. (35).

No aromatic hydrocarbons (polycyclic aromatic hydrocarbons), nor petroleum molecular markers were identified in detectable amounts. These markers have been identified previously in aerosols, particulate matter, and black crusts on European monuments as the result of air pollution (7).

DNA Sequence Analyses. Fatty acid analyses strongly suggested a biological input mainly due to the presence of cyanobacteria. This was corroborated by analyses based on DNA sequences extracted from the collected samples. Samples for the experimental procedure on DNA were collected and stored in the same way as for the other analyses. Since no special protocol was followed for DNA sample preservation, the analyses performed during this study were limited to identifying the DNA preserved during storage. Our analyses provided direct evidence of cyanobacteria in six out of seven samples investigated. This indicates that no particular difficulty arose in obtaining amplification by PCR in samples stored for 1 or 2 years, as previously reported by Shirkey et al. (36), who studied the cyanobacterium Nostoc commune during short- and long-term periods of desiccation.

A total of 30 clones were sequenced and intercompared, allowing them to be grouped into twelve distinct Operational Taxonomic Units (OTUs), following the criterion mentioned by Zimmerman et al. (37). The list of OTUs, their sample of origin, and taxonomic affiliation of the microorganisms represented by these sequences can be seen in Table 7 , provided as Supporting Information. The sequences retrieved during this study presented a percentage of similarity between 89 and 99\%, with their closest homologue sequences from GenBank (NCBI). Among the studied samples, 16S rRNA gene sequences were detected, closely related (92\% similarity) to chloroplasts belonging to the bryophyte Physcomitrella patens, a moss able to colonize diverse types of habitats (38). Thus, this finding confirms the presence of phototrophic cells from the Eukarya Domain in the studied samples.

Most of 16S rRNA sequences retrieved from the studied samples belong to the Cyanobacteria, specifically to the Order Nostocales. These cyanobacterial sequences were identified in all of the six samples with satisfactory PCR amplification products. The encountered sequences were mainly related to the genera Nostoc, Anabaena, and Cylindrospermum within the Nostocales. Thus, the results confirm the capability of the microorganisms represented by these sequences to form blackish biofilms on stone monuments.

Molecular surveys based on DNA together with fatty acid analysis undoubtedly confirm the presence of cyanobacteria as the major constituent of the biological communities present in the Iranian black deposits.

Microbiotic Crusts at Iranian Archaeological Sites. Considering the three possible sources of NCC, and excluding the presence of organic surface treatments on the sampled monuments, biological colonization and atmospheric deposition from combustion processes, such as soot and volatile organic compounds, are the only two possible origins of surface blackening. Soot deposition was disregarded by the inorganic fraction analysis. In addition, the presence of oxalates, the characteristic patterns of cyanobacterial compounds in the organic fraction, and the molecular analysis all point to a major biological contribution to the soiling of the Iranian monuments investigated.

The Iranian sites investigated appear to be covered by a microbiotic crust (see Figure 8), mainly composed of phototrophic organisms, principally cyanobacteria, as revealed by DNA and thermochemolysis analyses. Although the sampling campaign was not designed for microbiological studies, and therefore, the samples were not properly stored 
for a biological study, the data obtained from the phylogenetic sequences confirmed the presence of cyanobacteria (Nostocales) and provide some interesting clues to explain the microbial colonization occurring on the stone surfaces.

Microbiotic crusts are desert communities composed of diverse photosynthetic and non-photosynthetic organisms, including cyanobacteria and other prokaryotes, algae, lichens, non-lichenized fungi, etc (39). Desert crusts from the Colorado Plateau comprise a diverse, polyphyletic array of cyanobacteria, but no microscopic or molecular evidence for the presence of significant populations of eukaryotic algae have been obtained (40).

The crusts are also common in areas where there is sporadic water, as in the case of water leakage through rock, a natural phenomenon on cliff faces, observed in many countries, for example, in Spain, on a cliff decorated with rock art paintings (41).

Nostoc is one of the most broadly successful cyanobacterial genera. Most Nostoc biofilms or biomass have a black color when dried. Nostoc flagelliforme grows very slowly in desert steppe and bare areas in arid and semi-arid regions in northern and north-western China (42), forming black masses when dried.

The ability of Nostoc species to withstand desiccation is probably the key to their success in a variety of terrestrial habitats (43). There was no evidence of extensive degradation of DNA in cells of Nostoc comune after decades of desiccation (36), and one dried herbarium specimen grew when rehydrated after 107 years of desiccation (43). Clearly, the storage for 2 years, at room temperature, of naturally dried microbiotic crusts removed from the Iranian samples, did not affected the DNA of Nostoc. Protected against oxidative damage and degradation by desiccation, they were evidenced by amplification of $16 \mathrm{~S}$ rRNA gene sequences.

The desiccation/senescence of cyanobacteria gives rise to a blackening on the limestone surfaces, mainly due to chemical changes in the nucleic acids and lipid components, like chlorophyll, as well as the oxidation of unsaturated fatty acids accumulating in the cells $(11,36)$.

To sum up, the data obtained from the inorganic and organic analyses, and the identification of cyanobacterial sequences in the DNA extracts, clearly point toward a colonization by the Nostocales species as being responsible for the soiling and blackening of the Iranian monuments investigated.

\section{Acknowledgments}

This work was carried out under the research contract "Surface deposit identification on building materials of Iranian Cultural Heritage", as part of a collaboration between Institute ISAC-CNR and Centro Europeo di Venezia per la Conservazione del Patrimonio Architettonico (CENTROVE). We particularly thank the researchers of the Research Centre for Conservation of Cultural Relics (RCCCR) of Tehran for their support and collaboration during the sampling campaign. Thanks are also extended to Prof. Franco Prodi for the useful discussions on the general topic of the paper. Funding was also provided by the Consejería de Innovación, Ciencia y Empresa, Junta de Andalucía (to C.S.J.). This work follows the EC Project "Carbon content and origin of damage layers in European monuments" (CARAMEL, EVK4-CT-200000029). V.J was supported by an I3P (European Social Funds) contract and J.M.G. by a Ramón y Cajal, MEC contract.

\section{Supporting Information Available}

The list of OTUs, origin, and taxonomic affiliation of the microorganisms represented by DNA sequences extracted from the black deposits are reported in Table 7.

\section{Literature Cited}

(1) Spektor, D. M. A review of the scientific literature as it pertains to Gulf War illnesses. Vol. 6. Oil Well Fires. RAND, 1998. http:// www.gulflink.osd.mil/library/rowl/

(2) Hobbs, P. V.; Radke, F. L. Airborne studies of the smoke from the Kuwait oil fires. Science 1992, 256, 987-991.

(3) Laursen, K. K.; Ferek, R. J.; Hobbs, P. V. Emission factors for particles, elemental carbon and trace gases from the Kuwait oil fires. J. Geophys. Res. 1992, 97, 14991-14497.

(4) Ferek, R. J.; Hobbs, P. V.; Herring, J. A.; Laursen, K. K. Chemical composition of emissions from the Kuwait oil fires. J. Geophys. Res. 1992, 97, 14483-14489.

(5) Shirazi, S. A.; Rahmani, R.; Ventura, A.; Gianelle, V.; Fermo, P. SPM analysis as a key point in monitoring and assessment of damages to Iranian cultural heritage due to Kuwaiti oil well fire. PM2004, 1st Convegno Nazionale sul Particolato Atmosferico, University of Milano-Bicocca, 2004, poster B4.2. http://www.disat.unimib.it/chimamb/PM2004/Poster_2004.htm.

(6) Payne, C. UN commission awards compensation for environmental and public health damage from 1990-91. Gulf War. The American Society of International Law, 2005. http://www.asil.org/insights/2005/ 08/insights050810.html.

(7) Saiz-Jimenez, C. Deposition of airborne organic pollutants on historic buildings. Atmos. Environ. 1993, 27B, 77-85.

(8) Sabbioni, C. Mechanisms of air pollution damage to stone. In The Effects of Air Pollution on the Built Environment, Air Pollution Reviews; Brimblecombe, P., Ed; Imperial College Press: London, 2003; Vol. 2, pp 63-106.

(9) Sabbioni, C.; Zappia, G. Atmospheric-derived element tracers on damaged stone. Sci. Total Environ. 1992, 126, 35-48.

(10) Grossi, C. M.; Brimblecombe, P. Aesthetics of simulated soiling patterns on architecture. Environ. Sci. Tecnol. 2004, 38, 39713976.

(11) Saiz-Jimenez, C. Microbial melanins in stone monuments. Sci. Total Environ. 1995, 167, 273-286.

(12) Ghedini, N.; Sabbioni, C.; Bonazza, A.; Gobbi, G. Chemicalthermal quantitative methodology for carbon speciation in damage layers on building surfaces. Environ. Sci. Technol. 2006, 40, 939-944.

(13) Gugger, M.; Lyra, C.; Suominen, I.; Tsitko, I.; Humbert, J-F.; Salkinoja-Salonen, M.; Sivonen, K. Cellular fatty acids as chemotaxonomic marker of the genera Anabaena, Aphanizomenon, Microcystis, Nostoc and Planktothrix (cyanobacteria). Int. J. Syst. Evol. Microbiol. 2002, 52, 1007-1015.

(14) Saiz-Jimenez, C. Pyrolysis/methylation of soil fulvic acids: benzenecarboxylic acids revisited. Environ. Sci. Technol. 1994, 28, 197-200.

(15) Nübel, U.; Garcia-Pichel, F.; Muyzer, G. PCR primers to amplify 16 rRNA genes from cyanobacteria. Appl. Environ. Microbiol. 1997, 63, 3327-3332.

(16) Diez, B.; Pedros-Alio, C.; Marsh, T. L.; Massana, R. Application of denaturing gradient gel elctrophoresis (DGGE) to study the diversity of marine picoeukaryotic assemblages and comparison of DGGE with other molecular techniques. Appl. Environ. Microbiol. 2001, 67, 2942-2951.

(17) Gonzalez, J. M.; Ortiz-Martinez, A.; Gonzalez-del Valle, M. A. Laiz, L.; Saiz-Jimenez, C. An efficient strategy for screening large cloned libraries of amplified 16S rDNA sequences from complex environmental communities. L. Microbiol. Meth. 2003, 55, 459463.

(18) Garcia-Valles, M.; Vendrell-Saz, M.; Molera, J.; Blazquez, F. Interaction of rock and atmosphere: patinas on Mediterranean monuments. Environ. Geol. 1998, 36, 137-149.

(19) Ghedini, N.; Gobbi, G.; Sabbioni, C.; Zappia, G. Determination of elemental and organic carbon on damaged stone monuments. Atmos. Environ. 2000, 34, 4383-4391.

(20) Cachier, H. Carbonaceous combustions aerosol. In IUPAC Book on Atmospheric Particles; Harrison, R.M.; Van Grieken R., Eds.; Wiley: New York, 1998; pp 295-348.

(21) Rossi Manaresi, R. Oxalate patinas and conservation treatments. In The Oxalate Films: Origin and Significance in the Conservation of Works of Art; Realini, M., Toniolo, L., Eds.; Editeam, Milan, 1996; pp 113-127.

(22) Chalansonnet, S.; Largeau, C.; Casadevall, E.; Berkaloff, C.; Peniguel, G.; Couderc, R. Cyanobacterial resistant biopolymers. Geochemical implications of the properties of Schizothrix sp. resistant material. Org. Geochem. 1988, 13, 1003-1010.

(23) National Geoscience Database of Iran. Mining informat. http:// www.ngdir.ir/MiningInfo/MiningInfo.asp.

(24) Bonazza, A.; Sabbioni, C.; Ghedini, N. Quantitative data on carbon fractions in interpretation of black crusts and soiling on European built heritage. Atmos. Environ. 2005, 39, 2607-2618. 
(25) Karthikeyan, S.; Balasubramanian, R. Rapid extraction of water soluble organic compounds from airborne particulate matter. Anal. Sci. 2005, 21, 1505.

(26) Seaward, M. R. D. Lichens, agents of monumental destruction. Microbiol. Today 2003, 30, 110 .

(27) Saiz-Jimenez, C. Analytical pyrolysis of humic substances: pitfalls, limitations, and possible solutions. Environ. Sci. Technol. 1994, 28, 1173-1780.

(28) Dembitsky, V. M.; Srebnik, M. Variability of hydrocarbon and fatty acid components in cultures of the filamentous cyanobacterium Scytonema sp. isolated from microbial community "black cover" of limestone walls in Jerusalem. Biochemistry 2002, 67, 1276-1282.

(29) Poerschmann, J.; Parsi, Z.; Görecki, T.; Augustin, J. Characterization of non-discriminating tetramethylammonium hydroxideinduced thermochemolysis-capillary gas chromatography-mass spectrometry as a method for profiling fatty acids in bacterial biomasses. J. Chromatogr. A, 2005, 1071, 99-109.

(30) Haack, S. K.; Garchow, H.; Odelson, D. A.; Forney, L. J.; Klug, M. J. Accuracy, reproducibility, and interpretation of fatty acid methyl ester profiles of model bacterial communities. Appl. Environ. Microbiol. 1994, 60, 2483-2493.

(31) Ishida, Y.; Wakamatsu, S.; Yokoi, H.; Ohtani, H.; Tsuge, S. Compositional analysis of polyunsaturated fatty acis oil by onestep thermally assisted hydrolysis and methylation in the presence of trimethylsulfonium hydroxide. L. Anal. Appl. Pyrol. 1999, 49, 267-276.

(32) Saiz-Jimenez, C.; Garcia-Rowe, J.; Garcia del Cura, M. A.; OrtegaCalvo, J. J.; Roekens, E.; Van, Grieken, R. Endolithic cyanobacteria in Maastricht limestone. Sci. Total Environ. 1990, 94, 209220.

(33) Rezanka, T.; Dor, I.; Prell, A.; Dembitsky, V. M. Fatty acid composition of six freshwater wild cyanobacterial species. Folia Microbiol. 2003, 48, 71-75.

(34) Köster, J.; Volkman, J. K.; Rullkötter, J.; Scholz-Böttcher, B. M.; Rethmeier, J.; Fischer, U. Mono-, di- and trimethyl-branched alkanes in cultures of the filamentous cyanobacterium Calothrix scopulorum. Org. Geochem. 1999, 30, 1367-1379.
(35) Dembitsky, V. M.; Shkrob, I.; Dor, I. Separation and identification of hydrocarbons and other volatile compounds from cultured blue-green alga Nostoc sp. by gas chromatography-mass spectrometry using serially coupled capillary columns with consecutive nonpolar and semipolar stationary phases. $L$. Chromatogr. 1999, 682, 221-229.

(36) Shirkey, B.; McMaster, N. J.; Smith, S. C.; Wright, D. J.; Rodriguez, H.; Jaruga, P.; Birincioglu, M.; Helm, R. F.; Potts, M. Genomic DNA of Nostoc comune (Cyanobacteria) becomes covalently modified during long-term (decades) desiccation but is protected from oxidative damage and degradation. Nucleic Acids Res. 2003, 31, 2995-3005.

(37) Zimmermann, J.; Gonzalez, J. M.; Ludwig, W.; Saiz-Jimenez, C. Detection and phylogenetic relationships of a highly diverse uncultured acidobacterial community on paleolithic paintings in Altamira Cave using 23S rRNA sequence analyses. Geomicrobiol. J. 2005, 22, 379-388.

(38) Schaefer, D. G.; Zryd, J. P. The moss Physcomitrella patens, Now and Then. Plant Phvsiol. 2001, 127, 1430-1438.

(39) Evans, R. D.; Johansen, J. R. Microbiotic crusts and ecosystem processes. C. R. Plant Sci. 1999, 18, 183-225.

(40) Garcia-Pichel, F.; Lopez-Cortes, A.; Nübel, U. Phylogenetic and morphological diversity of cyanobacteria in soil desert crusts from the Colorado Plateau. Appl. Environ. Microbiol. 2001, 67, $1902-1910$.

(41) Saiz-Jimenez, C.; Hermosin, B. Thermochemolysis of the black deposits coating the ceiling and walls of Cueva del Encajero, Quesada, Spain. I. Anal. Appl. Pyrolvsis 1999, 49, 349-357.

(42) But, P. P-H.; Cheng, L.; Chan, P. K.; Lau, D. T-W.; But, J. W-H. Nostoc flagelliforme and faked items retailed in Hong Kong. $L$ Appl. Phycol. 2002, 14, 143-145.

(43) Dodds, W. K.; Gudder, D. A. The ecology of Nostoc. L. Phycol. 1995, 31, 2-18.

Received for review September 12, 2006. Revised manuscript received December 20, 2006. Accepted December 21, 2006.

ES062176S 